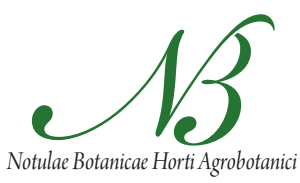

Cluj-Napoca

\title{
Fruit Quality of Nine Old Apple Cultivars
}

\author{
Tomislav JEMRIĆ, Martina Skendrović BABOJELIĆ*, Goran FRUK, Zoran ŠINDRAK \\ University of Zagreb, Faculty of Agriculture, Department of Pomology, Croatia; mskendrovic@agr.hr(*corresponding author)
}

\begin{abstract}
The quality of the nine old apple cultivars ('Gelber Bellefleur', 'Carević,' 'Čelenka', 'Crvena jesenska rebrača, 'Paradija', 'Paulaner Weinapfel,' 'Perovnjača, 'Winter Banana' and 'Zuccalmaggio') was studied. The cultivars 'Gelber Bellefleur', 'Crvena jesenska rebrača', 'Paulaner Weinapfel' and 'Winter banana' had the highest fruit mass, and 'Carević, 'Čelenka,' 'Paradija' and 'Zuccalmaggio' the lowest. The cultivar 'Gelber Bellefleur' had the highest fruit height and cultivar 'Čelenka' the smallest. The cultivar 'Perovnjača' had the highest fruit width, and cultivar 'Zuccalmaggio' the lowest. The cultivar 'Paradija' had the highest shape index and cultivar 'Perovnjača' the smallest. Among the red-coloured cultivars, the cultivars 'Carević' and 'Crvena jesenska rebrača' had significantly higher L and a-values, while the cultivar 'Čelenka' had significantly higher Chroma and Hue angles. Hue angle in this cultivar was $72 \%$ higher than in 'Crvena jesenska rebrača' and 51\% higher than in 'Carević, showing intensive red coloration of this cultivar. Among the yellow-coloured cultivars, 'Winter Banana' had the highest L-value. There were no significant differences in a-values among the cultivars 'Gelber Bellefleur', 'Paradija', and 'Zuccalmagio', which had the highest values. The cultivar 'Paulaner Weinapfel' had the highest b- and Chroma values, and there were no significant differences among cultivars in Hue angle. The cultivar 'Zuccalmaggio' had the highest firmness and 'Paulaner Weinapfel' the lowest. The cultivar 'Crvena jesenska rebrača' had the highest SSC, and 'Perovnjača' the smallest. The cultivar 'Perovnjača' had the highest TA, and there was a significant difference compared to 'Čelenka.' The cultivars 'Crvena jesenska rebrača, 'Paradija,' 'Winter Banana,' 'Paulaner Weinapfel' and 'Zuccalmagio' had the lowest TA and there were no significant differences among them. The cultivar 'Crvena jesenska rebrača' had the highest SSC/TA ratio, and 'Perovnjača' the lowest. There were no significant differences in seed number per fruit among cultivars. The main disadvantage of these cultivars is the small fruit size, which is an important trait for fresh consumption. Therefore, it is necessary to evaluate improving the fruit size in these cultivars by pruning, fertilizing and thinning before their reintroduction into production.
\end{abstract}

Keywords: biodiversity, conservation, fruit quality, Malus $\times$ domestica Borkh., pomology

\section{Introduction}

Old apple cultivars are generally characterized by quite their unusual pomological traits and have sometimes a lower external appeal with respect to standard apples (Bignami et al., 2003). Low external appearance and biennial bearing are the two main reasons for the loss of interest among apple growers to grow such cultivars. The range of apple cultivars in the European market has been significantly reduced to no more than 12 cultivars (Hecke, 2006). Donno et al. (2012) stated that in Italy more than $70 \%$ of orchards are planted with cultivar 'Golden Delicious'. This leads to genetic erosion and the loss of many local cultivars (Vujanić-Varga et al., 1994).

In comparison with standard cultivars, old apple cultivars have a wide range in flavour, aroma, sugar and acidcontent as well as higher firmness, total polyphenol and flavonoid content, vitamin $\mathrm{C}$ concentration and antioxidative potential (Hecke et al., 2006; Radunić et al., 2011; Balík et al., 2012; Donno et al., 2012). Internal quality (flavour, taste, crispness, etc.) ranks above appearance in importance among apple characteristics (Redalen, 1988). Flavour, taste and texture were the main reason for pur- chasing apples, as indicated by consumers (Harker, 2002), and phenolic compounds are important for prevention of cardiovascular diseases and cancer (Kroon and Williamson, 2005). Increased knowledge in old apple cultivars can help with diversification of the apple market (Itoiz and Royo, 2003; Pereira-Lorenzo et al., 2007; Donno et al., 2012) as well as maintenance of biodiversity and the historical and cultural links they represent (Donno et al., 2012).

Some old apple cultivars, such as 'Wagener' have high yielding potential and many of them carry genes for resistance to pests and diseases, drought tolerance and winter hardiness (Vujanić-Varga et al., 1994; Fischer and Fischer, 2004; Mitre et al., 2009; Tóth et al., 2012), together with unique fruit quality and wide genetic variability (Donno et al., 2012). These traits make them excellent basic material for fruit breeding.

Due to these reasons, many apple genetic resources conservation and utilization programs have been initiated worldwide (Vujanić-Varga et al., 1994; Hokanson et al., 1998; Noiton, 1998; Zhi-Qin, 1999; Gradinariu et al., 2003; Pereira Lorenzo et al., 2003; Pirlak et al., 2003; Ercis- 
li, 2004; Holland et al., 2006; Larsen et al., 2006; Mratinić and Fotirić-Akšić, 2011; 2012; Balík et al., 2012).

Many old apple cultivars have been abandoned by growers before the introduction of modern vegetative rootstocks, training forms and cultural practices. To evaluate their potential for reutilization, their response to modern fruit production methods must be known. Due to the insufficient information in the literature, the aim of this study was to evaluate the fruit quality of nine old apple cultivars on vegetative MM106 rootstock.

\section{Materials and methods}

The studied cultivars ('Gelber Bellefleur', 'Carevic', 'Celenka, 'Crvena jesenska rebrača, 'Paradija', 'Paulaner Weinapfel', 'Perovnjaca,' 'Winter Banana' and 'Zuccalmaggio') were harvested in the apple collection of the Department of Pomology, Faculty of Agriculture, University of Zagreb in Šašinovci ( $45^{\circ} 51^{\prime} 1^{\prime \prime} \mathrm{N}, 16^{\circ} 10^{\prime} 38^{\prime \prime}$ E). Trees were grafted on MM106 rootstock and planted at $5 \mathrm{~m}$ between rows and $4 \mathrm{~m}$ within rows. Cultural practices were regularly applied.

A sample of randomly picked 10 fruits per cultivar was harvested. The fruits were transported to the laboratory and visually inspected for damage and other defects. After determining fruit mass (g) on an analytical balance (Mettler-Toledo P1210, Mettler-Toledo International Inc., Columbus, USA) and fruit linear dimensions (fruit height and width, both in $\mathrm{mm}$ ) with a digital calliper (PCE-DCP 200 N, PCE Deutschland GmbH, Germany) and calculating fruit shape index as height:width ratio), fruits were selected for determining fruit colour, firmness, soluble solids content (SSC) and titratable acidity (TA).
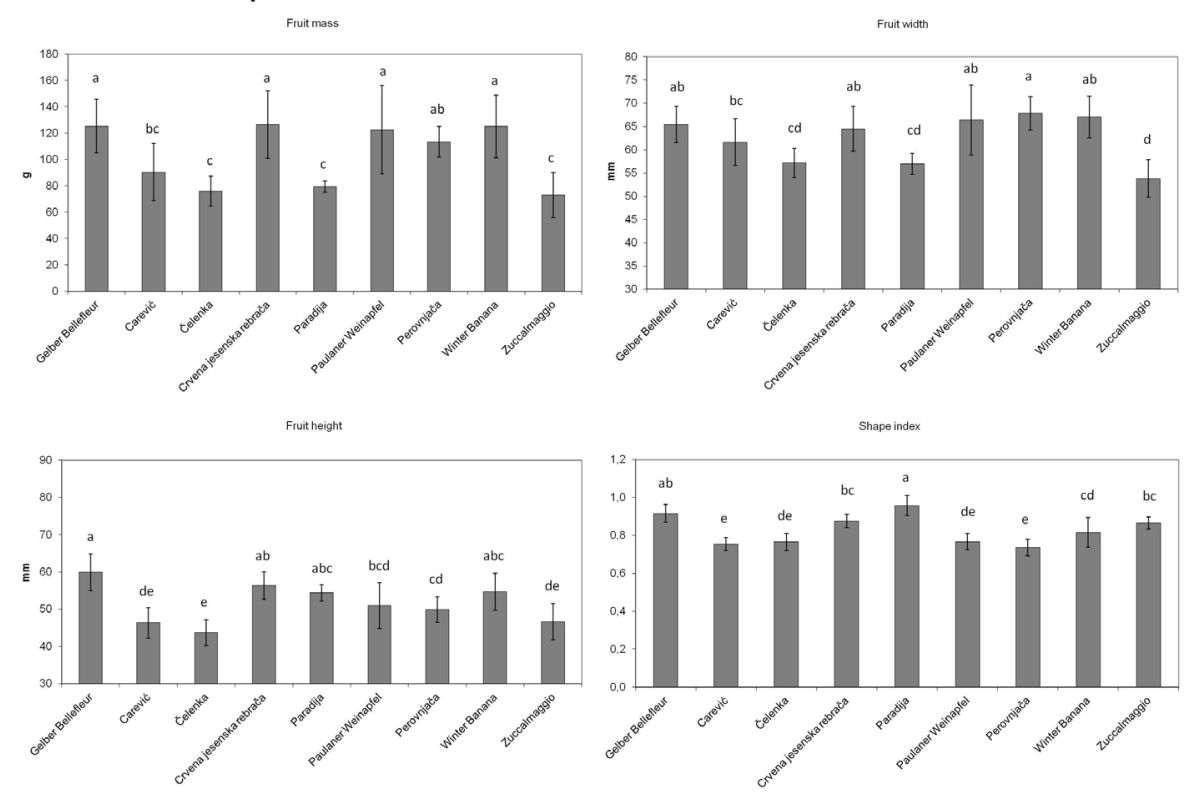

Fig. 1. Fruit mass, height, width and shape index of nine old apple cultivars

Note: Values marked by the same letter do not differ significantly at $p \leq 0.05$ according to

Tukey's HSD test. Vertical bars indicate standard deviation
Colour was measured according to CIE Lab system on a colorimeter Colortec PCM (ColorTec Associates, Inc., Clinton, USA). Colorimeter calibration was done with black and white plates supplied with the instrument and the fruit colour was represented with Hue angle $\left(\mathrm{H}^{\circ}\right)$ (McGuire, 1992).

Firmness $\left(\mathrm{kg} \cdot \mathrm{cm}^{-2}\right)$ was measured using an Effegi FT 327 penetrometer (Facchini SRL, Alfonsine, Italy) with $11 \mathrm{~mm}$ probe as the average value from four measurements made at opposite fruit sides at the equatorial fruit zone.

The juice from each fruit was extracted with an electric juicer and was used for determination of SSC ( ${ }^{\circ}$ Brix) with a refractometer ATAGO PAL-1 (Atago Co., Ltd., Tokyo, Japan) according to Mitcham et al. (1996). Titratable acidity (TA) was determined by titration with $0.1 \mathrm{~N}$ $\mathrm{NaOH}$ and expressed in percent of malic acid per $100 \mathrm{ml}$ of juice (Mitcham et al., 1996).

Data analysis was conducted with SAS software, version 9.2 (SAS Institute, Cary, NC, USA) using one way ANOVA and Tukey's HSD test at $p \leq 0.05$ level.

\section{Results and discussion}

The cultivars 'Gelber Bellefleur', 'Crvena jesenska rebrača,'Paulaner Weinapfel' and 'Winter banana' had the highest fruit mass, and 'Carević,' 'Čelenka', 'Paradija' and 'Zuccalmaggio' the lowest (Fig. 1), and differences were significant. The fruit mass of cultivars 'Carević' and 'Perovnjača' had intermediate values between these two groups (Fig. 1). Fruit mass was in agreement with the results obtained by other studies for old and local cultivars (Pirlak et al., 2003; Mitre et al., 2009; Mratinić and FotirićAkšić, 2011; 2012; Balík et al., 2012). In the cited studies,

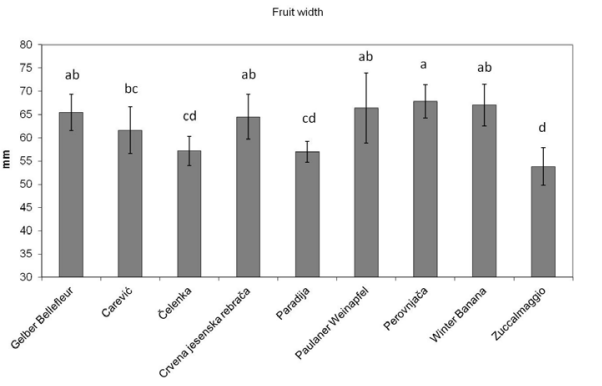


506

trees were also grafted on MM 106 rootstock, but grown in a closer space and under different ecological conditions (Mitre et al., 2009) or grown on seedling rootstocks in extensive cultural practices (Mratinić and Fotirić-Akšić, 2011; 2012). Therefore, it can be concluded that genetic factors have a stronger influence on fruit mass than ecological conditions, rootstock or cultural practices.

The cultivar 'Gelber Bellefleur' had the highest fruit height and 'Čelenka' the smallest (Fig. 1), and differences were significant. Other cultivars had intermediate values with no significant differences.

Cultivar 'Perovnjača' had the widest fruits, and 'Zuccalmaggio' the narrowest, with a significant difference. There were no significant differences among other cultivars (Fig. 1). The obtained results are comparable to local cultivars found in Turkey (Pirlak et al., 2003).

The cultivar 'Paradija' had the highest fruit shape index, followed by cultivars 'Crvena jesenska rebrača', 'Zuccalmaggio' and 'Winter Banana', and differences were significant. Cultivars 'Čelenka' and 'Paulaner Weinapfel' had significantly lower values and 'Perovnjača' the smallest (Fig. 1). Fruit size is affected by both exogenous (water availability and ambient temperature) and endogenous factors (crop load and genetic differences) as previously reported (Corelli-Grappadelli and Lakso, 2004). The most important factor affecting fruit size in this study are genetic differences, since all other factors were the same (water availability and ambient temperature) or similar (crop load). Fruit size is an important parameter for determining cultivar suitability for fresh consumption. Having this in mind, the fruit size in the studied cultivars was not satisfactory.

Among the red-coloured cultivars, 'Carevic' and 'Crvena jesenska rebrača' had significantly higher $\mathrm{L}$ - and avalues, while 'Čelenka' had significantly higher Chroma and Hue angle (Tab. 1). Hue angle in this cultivar was $72 \%$ higher than in 'Crvena jesenska rebrača' and 51\% higher than in 'Carević, showing nice and intensive red coloration of this cultivar.
Among the yellow-coloured cultivars, 'Winter Banana' had the highest L-value, with a significant difference. There were no significant differences in a-values among the cultivars 'Gelber Bellefleur', 'Paradija,', and 'Zuccalmagio' which had the highest values. The cultivar 'Paulaner Weinapfel' had the highest $\mathrm{b}$ - and Chroma value. There were no significant differences among the cultivars in Hue angle (Tab. 1).

The cultivar 'Zuccalmaggio' had the highest firmness and 'Paulaner Weinapfel' the lowest. The cultivars 'Gelber Bellefleur,' 'Winter Banana' and 'Crvena jesenska rebrača' had intermediate values and there were no statistical differences among them (Fig. 2). Similar firmness was found in modern apple cultivars (Mikulič Petkovšek et al., 2009; Drogoudi and Pantelidis, 2011). Crop load can affect fruit firmness (Wünsche et al., 2005; De Salvador et al., 2006; Saei et al., 2011), but in this study, crop load was similar in all cultivars. Therefore, the observed differences among cultivars are more the result of genetic factors.

The cultivar 'Crvena jesenska rebrača' had the highest SSC and 'Perovnjača' the lowest. All other cultivars had intermediate values with no significant differences (Fig. 2). SSC was similar to other studies with old apple and local cultivars (Mratinić and Fotirić-Akšić, 2011;2012) but higher than in standard cultivars (Iglesias et al., 2008) and local cultivars found in Turkey (Pirlak et al., 2003) and Czech Republic (Balík et al., 2012). However, some modern standard cultivars achieve SSC values similar to those in our study (Mikulič Petkovšek et al., 2009; Drogoudi and Pantelidis, 2011). High SSC in the present study might be partly attributed to low crop load (Wünsche $e t$ al., 2005; Saei et al., 2011), though its effect was the same in all studied cultivars since there were no differences in crop load between cultivars. Therefore, it can be concluded that, although SSC depends on other factors such as ecological conditions, rootstock and cultural practices, the observed differences in SSC in this study are the result of genetic factors.

Tab. 1. Colour of old apple cultivars (mean \pm SD)

\begin{tabular}{|c|c|c|c|c|c|}
\hline Cultivar & Lightness & a-value & $\mathrm{b}$-value & Chroma & Hue angle \\
\hline \multicolumn{6}{|c|}{ Yellow cultivars } \\
\hline 'G. Bellefleur' & $63.90 \pm 8.65^{c}$ & $-5.23 \pm 8.05^{a}$ & $39.80 \pm 9.52^{c}$ & $41.29 \pm 7.24^{c}$ & $94.14 \pm 19.65^{a}$ \\
\hline 'Paradija' & $69.89 \pm 2.04^{\mathrm{ab}}$ & $-6.55 \pm 2.00^{a}$ & $42.13 \pm 3.67^{b c}$ & $42.68 \pm 3.55^{c}$ & $98.94 \pm 2.83^{a}$ \\
\hline 'P. Weinapfel' & $68.50 \pm 2.79^{b c}$ & $-6.92 \pm 2.84^{\mathrm{ab}}$ & $51.24 \pm 9.55^{a}$ & $51.78 \pm 9.51^{\mathrm{a}}$ & $97.87 \pm 3.29^{a}$ \\
\hline 'Petrovača' & $66.36 \pm 1.85^{b c}$ & $-9.73 \pm 0.86^{a b}$ & $38.40 \pm 3.67^{c}$ & $39.63 \pm 3.62^{c}$ & $104.30 \pm 1.46^{a}$ \\
\hline 'Winter Banana' & $74.77 \pm 3.33^{a}$ & $-11.69 \pm 3.50^{b}$ & $47.74 \pm 5.72^{b}$ & $49.34 \pm 5.01^{b}$ & $104.17 \pm 4.98^{a}$ \\
\hline 'Zuccalmaggio' & $66.13 \pm 2.82^{b c}$ & $-6.53 \pm 1.32^{a}$ & $39.11 \pm 2.51^{c}$ & $39.68 \pm 2.43^{c}$ & $99.55 \pm 2.13^{a}$ \\
\hline \multicolumn{6}{|c|}{ Red cultivars } \\
\hline 'Carević’ & $47.03 \pm 4.53^{\mathrm{a}}$ & $13.25 \pm 3.86^{a}$ & $24.90 \pm 7.10^{\mathrm{ab}}$ & $28.87 \pm 4.83^{\mathrm{a}}$ & $60.31 \pm 12.95^{b}$ \\
\hline 'Čelenka’ & $37.39 \pm 4.15^{b}$ & $-0.41 \pm 8.36^{b}$ & $29.56 \pm 7.55^{a}$ & $30.70 \pm 7.33^{a}$ & $91.14 \pm 16.49^{a}$ \\
\hline 'CJR' & $44.44 \pm 5.38^{\mathrm{a}}$ & $12.40 \pm 2.46^{a}$ & $17.69 \pm 6.25^{b}$ & $22.18 \pm 4.18^{b}$ & $53.12 \pm 14.35^{b}$ \\
\hline
\end{tabular}

Note: values followed by the same letter within the same column and group of cultivars (Red or Yellow) are not significant do not differ significantly at $p \leq 0.05$ according to Tukey's HSD test: G. Bellefleur - Gelber Bellefleur, P. Weinapfel - Paulaner Weinapfel; CJR - Crvena jesenska rebrača 

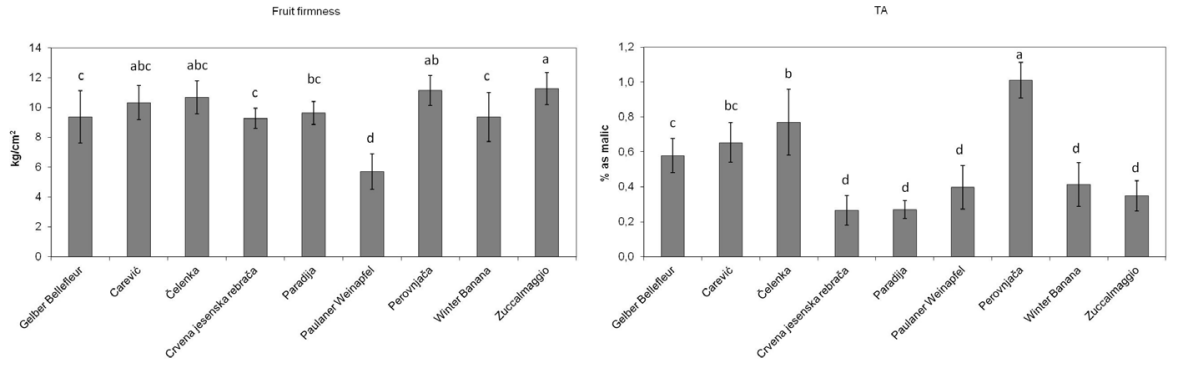

ssc
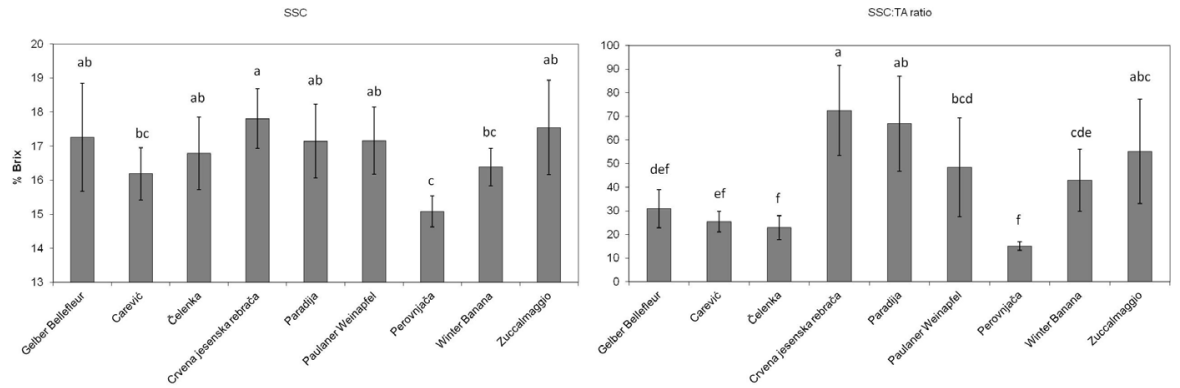

Fig. 2. Fruit firmness, SSC, TA and SSC: TA ratio of nine old apple cultivars

Note: Values marked by the same letter do not differ significantly at $p \leq 0.05$ according to Tukey's HSD test

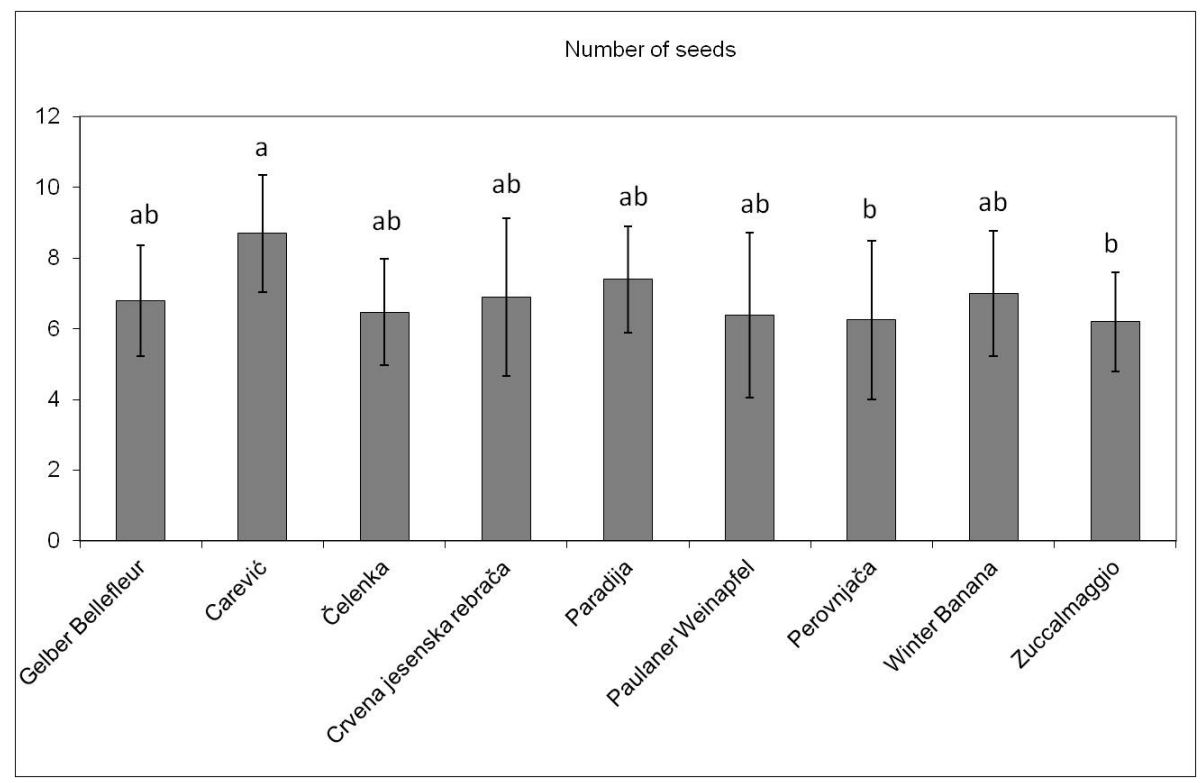

Fig. 3. Number of seeds per fruit in nine old apple cultivars

Note: Values marked by the same letter do not differ significantly at $p \leq 0.05$ according to Tukey's HSD test

The cultivar 'Perovnjača' had the highest TA, and there was a significant difference compared to 'Čelenka'. The cultivars 'Crvena jesenska Rebrača,' 'Paradija,' 'Winter Banana', 'Paulaner Weinapfel' and 'Zuccalmagio' had the lowest TA and there were no statistical differences among them (Fig. 2). Compared to the results for other apple cultivars, TA was in agreement for all cultivars in this study except for 'Čelenka' and 'Perovnjača', which had higher values. However, in some local cultivars, there is a wide range of TA levels which is in accordance with values obtained in this study (Mratinić and Fotirić-Akšić, 2011;2012), except for 'Perovnjača' which had higher values (Fig. 2). Pirlak et al. (2003) found even higher TA in some local cultivars in Turkey. Balík et al. (2012) found lower TA concentrations in local Czech cultivars. Fruit from light cropping trees have higher TA values (Saei et al., 2011), but this factor equally affected trees in this study and did not result in differences among the cultivars.

The cultivar 'Crvena jesenska rebrača' had the highest SSC:TA ratio, and 'Perovnjača' the lowest. Other culti- 
508

vars had intermediate values and there were no significant statistical differences among them (Fig. 2). The cultivars 'Crvena jesenska rebrača', 'Paradija', 'Paulaner Weinapfel', 'Winter Banana' and 'Zuccalmaggio' had high SSC:TA ratio. Moreover, apple cultivars with SSC:TA ratios lower than 20 are suitable for processing and cider production (Lea, 1995) such as 'Perovnjača', while other are more suitable for direct consumption.

The cultivar 'Carevic' had the highest seed number per fruit, and 'Zuccalmagio' the lowest. Other cultivars had intermediate values and there were no significant differences among them (Fig. 3). No relationship between seed number and fruit size was established in this study (Zisovich et al., 2012), which further supports the thesis of a strong genetic influence on fruit size.

\section{Conclusions}

On the basis results of this study, the cultivar 'Perovnjača' might be suitable for cider production, while the remaining cultivars are more suitable for direct consumption. The internal quality of these cultivars is high, though their fruit size is not satisfactory. Fruit size is an important trait for fresh consumption cultivars. Therefore, it is necessary to evaluate the improvement of fruit size by pruning, fertilizing and thinning before their reintroduction into production.

\section{Acknowledgements}

This study was supported by the Croatian Academy of Sciences through the project Pomological, phylometric and phenological research of old and local apple cultivars and SEEDNet project Characterization of apple local varieties (Malus $\times$ domestica Borkh.) from the South East European Region. We thank the Academy for the financial support.

\section{References}

Balík J, Rop O, Mlček J, Híc P, Horák M, Řezníček V (2012). Assessment of nutritional parameters of native apple cultivars as new gene sources. Acta Universitatis Agriculturae et Silviculturae Mendelianae Brunensis 60:27-38.

Bignami C, Scossa A, Vagnoni G (2003). Evaluation of old Italian apple cultivars by means of sensory analysis. Acta Hort 598:85-90.

Corelli-Grappadelli L, Lakso AN (2004). Fruit development in deciduous tree crops as affected by physiological factors and environmental conditions. Acta Hort 636:425-441.

De Salvador FR, Fisichella M, Fontanari M (2006). Correlations between fruit size and fruit quality in apple trees with high and standard crop load levels. J Fruit Ornam Plant Res 14 (Suppl. 2):113-122.

Donno D, Beccaro GL, Mellano MG, Torello Marinoni D, Cerutti AK, Canterino S, Bounous, G (2012). Application of sensory, nutraceutical and genetic techniques to create a quality profile of ancient apple cultivars. Journal of Food Quality 35:169-181.

Drogoudi PD, Pantelidis G (2011). Effects of position on canopy and harvest time on fruit physico-chemical and antioxidant properties in different apple cultivars. Sci Hortic 130:752-760.

Ercisli SA (2004). A short review of the fruit germplasm resources of Turkey. Genet Resou Crop Ev 51:419-435.

Fischer M, Fischer C (2004). Genetic resources as basis for new resistant apple cultivars J Fruit Ornam Plant Res 12:63-76.

Gradinariu G, Istrate M, Dascalu M, Gradinariu F, Janick J (2003). Native apple germplasm in Romania. Acta Hort 622:485-488.

Harker R (2002). Improve fruit quality to increase demand. Good Fruit Grower 53:27.

Hecke K, Herbinger K, Veberič R, Trobec M, Toplak H, Štampar F, Keppel H, Grill D (2006). Sugar-, acid- and phenol contents in apple cultivars from organic and integrated fruit cultivation. Eur J Clin Nutr 60:1136-1140.

Hokanson SC, Forsline PL, McFerson JR, Lamboy WF, Aldwinckle HS, Luby JJ, Djangaliev AD (1998). Ex situ and in situ conservation strategies for wild Malus germpalsm in Kazakhstan. Acta Hort 484:85-92.

Holland D, Bar-Yaakov I, Trainin T, Hatib K (2006). Old deciduous fruit trees of the Rosaceae in Israel and their utilization in modern agriculture and breeding. Israel Journal of Plant Sciences 54:169-177.

Iglesias I, Echeverrıa G, Soria Y (2008). Differences in fruit colour development, anthocyanin content, fruit quality and consumer acceptability of eight 'Gala' apple strains. Scientia Hortic 119:32-40.

Itoiz R, Royo B (2003). Isoenzymatic variability in an apple germplasm bank. Genet Resour Crop Ev 50:391-400.

Kroon P, Williamson G (2005). Polyphenols: dietary components with established benefits to health? J Sci Food Agric 85:1239-1240.

Larsen AS, Asmussen CB, Coart E, Olrik DC, Kjær ED (2006). Hybridization and genetic variation in Danish populations of European crab apple (Malus sylvestris). Tree Genet Genomes 2:86-97.

Lea AGH (1995) Cider making, p. 66-96. In: Lea AGH, Piggott JR (Eds.). Fermented Beverage Production. Blackie and Sons.

McGuire RG (1992). Reporting of objective color measurements. HortScience 27:1254-1255.

Mikulič Petkovšek M, Štampar F, Veberič R (2009). Changes in the inner quality parameters of apple fruit from technological to edible maturity. Acta Agriculturae Slovenica 93:1729.

Mitcham B, Cantwell M, Kader A (1996) Methods for determining quality of fresh commodities. Perishables Handling Newsletter Issue No. 85:1-6.

Mratinić E, Fotirić Akšić M (2011). Evaluation of phenotypic 
diversity of apple (Malus sp.) germplasm through the principle component analysis. Genetika 43:331-340.

Mratinić E, Fotirić Akšić M (2012). Phenotypic Diversity of Apple (Malus sp.) Germplasm in South Serbia. Braz Arch Biol Technol 55:349-358.

Noiton D, Hofstee M, Alspach P, Brewer L, Howard C (1998). Increasing genetic diversity for apple breeding: a preliminary report. Acta Hort 484:105-108.

Pereira-Lorenzo S, Ramos-Cabrer AM, Ascasíbar Errasti J, Piñeiro-Andión J (2003). Analysis of apple germplasm in Northwestern Spain. J Am Soc Hort Sci 128:67-84.

Pereira-Lorenzo S, Ramos-Cabrer AM, DiázHernández MB (2007). Evaluation of genetic identity and variation of local apple cultivars (Malus $\times$ domestica) from Spain using microsatellite markers. Genet Resour Crop Ev 54:405-420.

Pirlak L, Güleryüz M, Aslantaş R, Eşitken A (2003). Promising native summer apple (Malus domestica) cultivars from north-eastern Anatolia, Turkey. New Zealand Journal of Crop and Horticultural Science 31:311-314.

Radunić M, Klepo T, Strikić F, Lukić D, Maretić M (2011). Karakteristike sorata jabuka (Malus x domestica Borkh.) uzgajanih na području Žrnovnice. Pomologia Croatica 17:1117.

Redalen G (1988). Quality assessment of apple cultivars and selections. Acta Hort 224:441-447.

Saei A, Tustin DS, Zamani Z, Talaie A, Hall AJ (2011). Crop- ping effects on the loss of apple fruit firmness during storage: The relationship between texture retention and fruit dry matter concentration. Sci Hortic 130:256-265.

Tóth M, Ficzek G, Honty K, Hevesi M, Király H (2012). Evaluation of old Carpathian apple cultivars as genetic resources of resistance to fire blight (Erwinia amylovora). Trees (published on-line). DOI: dx.doi.org/10.1007/s00468-0120814-4

Vujanič-Varga D, Ognjanov V, Balaž J, Macet K, Krstič M (1994). Genetic resources in apple, pear and vineyard peach populations in former Yugoslavia. Euphytica 77:155-159.

Wünsche JN, Greer DH, Laing WA, Palmer JW (2005). Physiological and biochemical leaf and tree responses to crop load in apple. Tree Physiology 25:1253-1263.

Zhi-Qin Z (1999). The apple genetic resources in China: The wild species and their distributions, informative characteristics and utilization. Genet Resour Crop Ev 46:599-609.

Zisovich AH, Goldway M, Schneider D, Steinberg S, Stern E, Stern RA (2012). Adding bumblebees (Bombus terrestris L., Hymenoptera: Apidae) to pear orchards increases seed number per fruit, fruit set, fruit size and yield. Journal of Horticultural Science and Biotechnology 87:353-359. 